Historia Slavorum Occidentis

2021, nr 1 (28)

ISSN 2084-1213

DOI: $10.15804 /$ hso210107

Sylwester Gardocki (Warszawa)

ORCID: 0000-0002-1703-0172

\title{
Imperializm w polityce zagranicznej Rosji carskiej oraz ZSRR
}

Słowa kluczowe: Rosja, imperializm, polityka zagraniczna

Keywords: Russia, imperialism, foreign policy

\begin{abstract}
The aim of this article is to take a synthetic look at Tsarist Russia (from the $17^{\text {th }}$ century onwards) and the USSR through ideas and deeds which marked Russian political thinking and action and involved an intent to extend the influence to other countries or territories.
\end{abstract}

\section{Wstęp}

Można przedstawić wiele definicji pojęcia, ale niewątpliwie imperializm (łac. imperare - „rządzić”) to najkrócej polityka państwa zakładająca stałe dążenie do rozszerzania wpływów politycznych, militarnych, gospodarczych i kulturowych na inne państwa lub szerzej terytoria zewnętrzne. Tak rozumianym pojęciem autor będzie się posługiwał poniżej. Celem artykułu jest próba syntetycznego spojrzenia na Rosję carską (począwszy od XVII w.) oraz na ZSRR przez pryzmat idei i działań obecnych w rosyjskim myśleniu i działaniu politycznym, zakładających dążenie do rozszerzania wpływów na inne państwa lub terytoria.

Analizowany materiał autor podzielił na dwie części. W części pierwszej zostaną przedstawione oraz poddane analizie główne założenia oraz realne działania 
realizujące cele polityki zagranicznej Rosji carskiej. Część druga jest poświęcona imperialnym i mocarstwowym ambicjom ZSRR. Założeniem i celem autora jest analiza przyjmowanych politycznych założeń i realnych działań $\mathrm{w}$ ramach polityki zagranicznej Rosji carskiej oraz ZSRR, w szczególności w kontekście pojawiania się pierwiastków imperialnego i mocarstwowego myślenia oraz działania.

W aspekcie metodologicznym, w tekście wykorzystano analizę źródłową dokumentów, metodę genetyczną dotyczącą analizy źródeł, pochodzenia zjawisk i zachowań w imperialnej polityce Rosji i ZSRR oraz metodę porównawczą odnoszącą się do aspektów imperialnej polityki Rosji carskiej i ZSRR.

\section{Imperializm jako podstawowa determinanta polityki zewnętrznej Rosji carskiej}

Mocarstwowość Rosji podyktowana możliwością prowadzenia z sukcesem ekspansji terytorialnej stała się aż po czasy obecne kluczowym elementem $\mathrm{w}$ analizie polityki zagranicznej tego państwa. Odsunięcie zagrożenia przejęcia tronu moskiewskiego w okresie „wielkiej smuty” przez syna króla polskiego Zygmunta III Wazę i wstąpienie na tron władców z dynastii Romanowów zapoczątkowały trwały marsz ku wzmacnianiu potęgi państwa rosyjskiego i realizację aspiracji imperialnych.

Począwszy od XVII w., Rosja znacznie poszerzała swoje terytorium, wchodząc do panteonu ówczesnych mocarstw europejskich i światowych. Panowanie Piotra I Wielkiego stanowiło początek rosyjskiej polityki imperialnej. Piotr I zmienił system organizowania armii, powołując do wojska chłopów na dożywotnią służbę zamiast pańszczyzny, przeniósł stolicę Rosji do nowo budowanej stolicy - Piotrogrodu (Sankt Petersburg) i starał się zreformować państwo. Chciał je przeobrazić na wzór tego, co sam zobaczył podczas swoich podróży po Europie Zachodniej. Niestety reformy Piotra I nie odmienily oblicza gospodarczego Rosji m.in. z powodu wzmocnienia systemu poddaństwa, co skutecznie uniemożliwiło rozwój kapitalizmu. W 1721 r. senat nadał Piotrowi I tytuł „Imperatora” jako dowód jego mocarstwowych dokonań ${ }^{1}$.

Rządy carycy Katarzyny II są uznawane za znaczący okres w rozwoju rosyjskiego imperializmu. To w czasach jej panowania (1762-1796) ludność Rosji wzrosła niemalże dwukrotnie. Było to przede wszystkim wynikiem udanych podbojów te-

1 K. Pietkiewicz, Historia państwa rosyjskiego, [w: ] Wprowadzenie do studiów wschodnioeuropejskich, cz. 3: Rosja, red. A. Mironowicz, Lublin 2013, s. 26. 
rytorialnych, w tym udziału Rosji w rozbiorach Polski, i wygranych wojen z Turcją. Rosja uzyskała szeroki dostęp do Morza Czarnego oraz zajęła Krym, który do tego czasu pozostawał pod panowaniem sprzymierzonego z Turcją Chanatu Krymskiego. Zbudowano nad Morzem Czarnym Odessę, na Krymie Symferopol i Sewastopol. Plany mocarstwowe Katarzyny II były dalekosiężne. Jeszcze w trakcie wojen z Turcją Katarzyna II zakładała odbicie spod panowania Turcji wszystkich ziem europejskich, włącznie z Konstantynopolem, który miałby wrócić do Grecji, a na czele tego państwa miał stanąć monarcha Konstanty - wnuk Katarzyny II. Podobnie ekspansywny scenariusz Katarzyna II zakładała wobec rewolucyjnej Francji. Szykowano się do interwencji w ramach korpusu składającego się z 60 tys. żołnierzy. Plany te zniweczyła śmierć Katarzyny II².

Panowanie cara Aleksandra I przypadło na czas trudnych dla Europy i Rosji wojen napoleońskich. Wojsko rosyjskie w wyniku strategicznych działań defensywnych pod dowództwem Michaiła Kutuzowa stoczyło w 1812 r. bitwę pod Borodino. Pomimo olbrzymich strat armii carskiej Napoleonowi nie udało się całkowicie rozbić przeciwnika. Wojskom francuskim udało się wprawdzie wkroczyć do ogołoconej Moskwy, ale było to iluzoryczne zwycięstwo. Wykończona armia Napoleona nie była w stanie efektywnie prowadzić dalej działań zbrojnych i została zmuszona do odwrotu ${ }^{3}$.

Po tych wydarzeniach i po zakończonym Kongresie Wiedeńskim w 1815 r. wzmocnionym zawarciem „Świętego Przymierza” Rosja przez następne prawie pół wieku wraz z Austrią, Prusami, Anglią, a potem również Francją, stała się trwałym i ważnym elementem „koncertu mocarstw”. Celem „Świętego Przymierza” było utrzymywanie równowagi pomiędzy państwami, tak aby nie doszło do powtórki wydarzeń z epoki napoleońskiej.

Aleksandrowi I udało się nieznacznie poszerzyć granice terytorialne Rosji. W wyniku wojny ze Szwecją Rosja w 1809 r. przejęła kontrolę nad Finlandią. Wojna z Turcją zakończona układem w Bukareszcie i zatrzymaniem Besarabii nie przyniosła oczekiwanych rezultatów. Rosja nie uzyskała całej Mołdawii i Wołoszczyzny, zatem granice imperium nie przesunęły się i cel terytorialnego przybliżenia się do Konstantynopola nie został zrealizowany ${ }^{4}$.

Po śmierci Aleksandra I carem został jego brat Mikołaj. Panowanie Mikołaja I w polityce zagranicznej charakteryzowało się realizowaniem aspiracji mocarstwo-

2 L. Bazylow, P. Wieczorkiewicz, Historia Rosji, 2006, s. 176-180.

3 Tamże, s. 199.

4 T. Chapman, Imperial Russia 1801-1905, London-New York 2001, s. 27-28. 
wych szczególnie w kierunku Bałkanów i Kaukazu. Na salonach Europy Rosja była uznawana za mocarstwo, które dysponując dużą i silną armią, miało możliwość angażowania się w wiele europejskich sporów. Czar prysł z nadejściem wojny krymskiej, która zakończyła okres istnienia „koncertu mocarstw” i jednocześnie obnażyła nieporadność militarną Rosji. Do tego czasu Rosja dość skutecznie realizowała plany imperialne.

Mikołaj I postawił sobie za cel rozwiązanie sprawy cieśnin czarnomorskich i tym samym zagwarantowania swobodnego przepływu przez te przesmyki morskie przy jednoczesnym założeniu, że obce siły morskie nie będą mogły wpływać na wody Morza Czarnego. W 1828 r. rozpoczęła się kolejna wojna rosyjsko-turecka, którą zakończył pokój podpisany w Adrianopolu. Na mocy tego układu Turcja przyznała autonomię Mołdawii i Wołoszczyźnie, zgadzając się przy tym na obecność wojsk rosyjskich na tych terytoriach. Ponadto Rosja poszerzyła swoje nabytki na kaukaskim wybrzeżu Morza Czarnego i jako „samowolny” patron sprawy greckiej wymusiła na Turcji obietnicę autonomii dla Grecji ${ }^{5}$. Podczas konfliktu pomiędzy wasalnym Egiptem rządzonym przez Muhammada Alego a sułtanem tureckim Mahmudem II wojska egipskie zajęły Syrię i zbliżyły się do Anatolii. Car Mikołaj I umiejętnie wykorzystał tę sytuację i w tym sporze stanął po stronie sułtana tureckiego. Rosja wysłała niewielką flotę do Konstantynopola, a wojska rosyjskie w liczbie ok. 14 tys. żołnierzy pojawiły się w stolicy Imperium Osmańskiego. To w zupełności wystarczyło, aby sułtan turecki zawarł z carem Rosji kolejne porozumienie. W 1833 r. w Unkiar-Iskielessi zawarto traktat, na mocy którego Turcja gotowa była zamknąć cieśniny dla wrogich Rosji obcych okrętów wojennych. W zamian Rosja zobowiązała się do udzielenia w razie potrzeby pomocy militarnej. Na mocy tego traktatu carowi Mikołajowi I udało się osiągnąć silną, jak nigdy wcześniej pozycję względem Turcji i jednocześnie uzyskać znaczną przewagę w odniesieniu do Bliskiego Wschodu w relacjach z Francją i Wielką Brytanią ${ }^{6}$.

Wojna krymska (1853-1856) stonowała mocarstwowe zapędy cara Mikołaja I, który zmarł w trakcie trwania tego konfliktu w 1855 r. (okoliczności śmierci cara są niejasne, w niektórych kręgach uważano, że car popełnił samobójstwo, nie radząc sobie z porażkami podczas wojny krymskiej) ${ }^{7}$. Jednocześnie prysnął czar Rosji jako „prawdziwego” mocarstwa, będącego w stanie odeprzeć ataki Anglii i Francji, które

5 L. Bazylow, P. Wieczorkiewicz, Historia Rosji, s. 228-231.

6 T. Chapman, Imperial Russia, s. 69.

7 Zob. L. Bazylow, P. Wieczorkiewicz, Historia Rosji, s. 239. 
stanęły po stronie tureckiej. Wojnę krymską zakończył traktat paryski z 1856 r. Traktat znacznie zmniejszał rolę Rosji na Bliskim Wschodzie, m.in. zakazywał posiadania przez Rosję floty na Morzu Czarnym i przywracał - nadszarpniętą wcześniej - pozycję Turcji w regionie ${ }^{8}$.

Przy okazji porażki i upokorzenia Rosji w wojnie krymskiej należy wspomnieć o doktrynie panslawizmu, która w tych okolicznościach zaczęła się dynamicznie rozwijać. Doktryna ta nawoływała do zjednoczenia wszystkich Słowian pod przywództwem Rosji i sprawnie wpisywała się w imperialne działania państwa rosyjskiego. Znaczenie doktryny rosło także w kontekście rosyjskiej polityki bałkańskiej: oprócz pierwiastka religijnego panslawizm w odniesieniu do Bułgarii czy Serbii oferował doktrynę niezwykle kompatybilną. Z czasem panslawizm stał się doktryną państwową Rosji carskiej popieraną przez Cerkiew prawosławną ${ }^{9}$.

Zresztą Cerkiew prawosławna wniosła istotny wkład w kształtowanie się polityki imperialnej carskiego państwa i stanowiła przy tym spoiwo wielonarodowego państwa. Koncepcja „Trzeciego Rzymu” sformułowana przez mnicha Filoteusza zintegrowała Państwo Moskiewskie i nadała mesjanistyczny wymiar działaniom politycznym. Reforma Cerkwi dokonana przez Piotra I uzależniła ją od kontroli władzy państwowej. Kluczową rolę odgrywał tu nadzorowany przez państwo Święty Synod. Cerkiew wówczas stała się instytucją służebną wobec imperialnej polityki rosyjskiej i było to zjawisko trwałe. W przekazie Cerkwi władca był dobrym „Ojczulkiem" i jeśli w państwie rosyjskim działo się źle lub naród cierpiał, to winni byli dworzanie i urzędnicy, którzy wykorzystywali swoją pozycję i oszukiwali cara rzekomo nieświadomego ich nadużyć. Ta wiara ludu w nieomylność i boskość cara stanowiła endogenny fundament przekonania, że to, co czyni władca, jest słuszne ${ }^{10}$.

Kolejny etap rządów rozpoczęło panowanie młodszego brata Mikołaja I - Aleksandra II (szykowany na następcę cara jego brat Konstanty - naczelny wódz armii Królestwa Polskiego - zrzekł się praw do tronu jeszcze za życia cara Mikołaja I). W polityce zagranicznej car Aleksander II starał się zrewidować ustalenia traktatu paryskiego kończącego wojnę krymską. Udało się to uzyskać dopiero po kilkunastu latach na konferencji mocarstw (już w gronie zjednoczonych Niemiec i Włoch)

8 W. Dobrzycki, Historia stosunków międzynarodowych w czasach nowożytnych 1815-1945, Warszawa 1996, s. 55-56.

9 P. Eberhardt, Rosyjski panslawizm jako idea geopolityczna, „Nowa Geopolityka”, 19.05.2012, https://geopolityka.net/rosyjski-panslawizm-jako-idea-geopolityczna/ [dostęp: 5 XI 2020].

10 W. Zieliński, Rosja - strategia imperium, Ante Portas. Studia nad bezpieczeństwem 2016, nr 1, s. 356-357. 
w Londynie w 1871 r., gdzie podpisano traktat, na mocy którego Rosja została zwolniona z demilitaryzacji wybrzeża Morza Czarnego. Od tego czasu Rosja zaczęła bardziej angażować się w sprawy europejskie, m.in. wskrzeszono sojusz trzech cesarstw: Niemiec, Rosji i Austro-Węgier ${ }^{11}$. Po zawarciu układu w Londynie Rosja dążyła do ponownego osłabienia Turcji, uznając ją za główną przeszkodę dla swojej ekspansji bałkańskiej i śródziemnomorskiej. W tym celu Rosja przystąpiła najpierw do działań dyplomatycznych razem z innymi mocarstwami europejskimi potępiającymi sułtana tureckiego za brak reform. W efekcie sojusz trzech cesarzy i układ z Austro-Węgrami, które zagwarantowały Rosji neutralność przy rozpoczęciu działań wojennych, okazał się nadzwyczaj korzystny dla Rosji. Car Aleksander II rozpoczął w kwietniu 1877 r. działania wojenne na dwóch frontach - bałkańskim i kaukaskim. Na terenie Bułgarii doszło do wielomiesięcznego oblężenia twierdzy Plewna, ostatecznie zdobytej w grudniu 1877 r. Na Kaukazie natomiast wojska rosyjskie podeszły aż pod twierdzę Kars. W styczniu 1878 r. zawarto rozejm ${ }^{12}$.

Układ pokojowy podpisano w marcu 1878 r. w San Stefano pod Stambułem. Nastąpiło to jednak w obecności floty brytyjskiej na wodach tureckich. Sam układ $\mathrm{w}$ wyniku presji pozostałych mocarstw europejskich nie miał już większego znaczenia, bowiem poddano go rewizji na konferencji w Berlinie odbywającej się w czerwcu i lipcu $1878 \mathrm{r}$. W efekcie tego plany rosyjskie o utworzeniu Wielkiej Bułgarii $\mathrm{z}$ terytorium Imperium Osmańskiego zostały zniweczone i powstało małe Księstwo Bułgarii. Pomimo nabytków na Zakaukaziu rezultaty konferencji berlińskiej okazały się dla Rosji dużym rozczarowaniem ${ }^{13}$.

Z kolei, co warto podkreślić, Rosja w okresie panowania Aleksandra II znacznie rozszerzyła swoje granice na kontynencie azjatyckim. Działania cara stanowiły kontynuację polityki poprzedników. W 1860 r. Rosja zawarła w Pekinie układ z Chinami, co w kontekście aspiracji mocarstwowych, eksploracji i ekspansji na Dalekim Wschodzie należy uznać za bardzo ważne porozumienie. Układ określił granicę rosyjsko-chińską i umożliwił Rosji założenie Władywostoku na Dalekim Wschodzie. Z kolei porozumienie z Japonią zawarte w 1875 r. w Petersburgu zakładało, że Sachalin pozostaje w granicach Rosji, Wyspy Kurylskie zaś w całości stanowią domenę Japonii ${ }^{14}$. Rosja opanowała też cały Kaukaz, ustanawiając w Tyflisie (Tbilisi) na-

\footnotetext{
11 T. Chapman, Imperial Russia, s. 112-113.

12 W. Dobrzycki, Historia, s. 154.

13 W.E. Mosse, Alexander II and the Modernization of Russia, New York 1976, s. 132.

14 T. Chapman, Imperial Russia, s. 115.
} 
miestnika w osobie feldmarszałka Aleksandra Bariatinskiego. Długotrwałe powstanie kaukaskie pod wodzą Szamila zostało zdławione, a sam Szamil wzięty przez Rosjan do niewoli. Siły rosyjskie zaczęły też kontrolować obszary południowego Morza Kaspijskiego. Po drugiej stronie wybrzeża, naprzeciw Baku, założono Krasnowodsk (obecnie Turkmenbaszy). Podbój obszarów Turkiestanu w Azji Środkowej zakończył się sukcesem. Emiraty Buchary i Chiwy do 1873 r. uznały zwierzchność Rosji, a miasta takie jak Taszkient, Samarkanda, Buchara znalazły się w jej granicach ${ }^{15}$.

Po zabójstwie cara Aleksandra II w 1881 r. przez organizację anarchistyczną „Narodnaja Wola” przywódcą Rosji został car Aleksander III Romanow, syn Aleksandra II. W okresie swojego panowania, co było wyraźnym odstępstwem od reguły, Aleksander III nie prowadził żadnych wojen. Wynikało to z pewnością po części z wydarzeń związanych z zabójstwem ojca cara i w konsekwencji potrzeby ustabilizowania sytuacji wewnętrznej w państwie. W polityce zagranicznej Aleksander III wyraźnie skoncentrował się na Europie, w tym na Bałkanach, i starał się przy tym zachować polityczną równowagę. Odwrotnie do wcześniejszych relacji nastąpiło znaczne pogorszenie stosunków Rosji z Bułgarią, nawet pomimo tego, że przywódca Bułgarii Aleksander I Battenberg był spokrewniony z carem Aleksandrem III. Niewielkie zainteresowanie cara Azją w sensie ekspansji nie oznaczało, że obszar ten był pozostawiony sam sobie. Car przyczynił się do rozwoju Dalekiego Wschodu i Syberii, inicjując budowę kolei transsyberyjskiej w $1891 \mathrm{r}^{16}$ (projekt miał być ukończony w 1903 r.).

W 1894 r. po śmierci cara Aleksandra III na tron wstąpił Mikołaj II Romanow. Podczas swojego panowania musiał stawić czoła niepokojom wewnątrz państwa (rewolucja z 1905 r.) oraz starał się z różnym skutkiem utrzymać pozycję Rosji na arenie międzynarodowej.

W Europie car próbował kontynuować realizację aspiracji mocarstwowych Rosji. Musiał się jednak liczyć z polityką pozostałych mocarstw europejskich. W okresie formowania się bloków państw w Europie Rosja stała się częścią Trójporozumienia (ententy), które ostatecznie uformowało się po zawarciu porozumienia rosyjsko-brytyjskiego w 1907 r. ${ }^{17}$ Jednak największym ciosem za panowania cara Mikołaja II była uwłaczająca godności imperium porażka z Japonią podczas wojny toczonej z tym państwem w latach 1904-1905. Car kierował się przekonaniem o łatwym

\footnotetext{
15 W.E. Mosse, Alexander II, s. 122-124.

16 T. Chapman, Imperial Russia, s. 135.

17 Szerzej zob.: W. Dobrzycki, Historia, s. 168-171.
} 
zwycięstwie, podobnie myśleli żołnierze i oficerowie. W notatkach jednego z nich zapisano, że wojna z Japonią będzie łatwa, a „pokój zostanie zawarty w Tokio w przeciągu trzech tygodni od pierwszego wystrzału” ${ }^{18}$. W rezultacie car stracił prawie całą swoją flotę. Jednak najgorsza była utrata prestiżu mocarstwa na Dalekim Wschodzie, również w kontekście rywalizacji w Europie. Japonia uzyskała też liczne koncesje w Korei kosztem Rosji, a także południowy Sachalin ${ }^{19}$.

Kolejnym następstwem porażki na Dalekim Wschodzie były niepokoje społeczne, które przeobrazily się w rewolucję 1905 r. Wzrost cen i trudy życia zmusily robotników i inne grupy społeczne do masowych wystąpień przeciwko carowi. Mikołaj II użył siły, aby spacyfikować protesty („Krwawa niedziela w Petersburgu”) ${ }^{20}$. Chociaż udało mu się opanować sytuację, to rewolucję z 1905 r. można uznać za preludium do wydarzeń z 1917 r. i upadku caratu w Rosji.

Panowanie cara zakończyło się tragicznie w 1917 r., kiedy w wyniku rewolucji lutowej odsunięto go od władzy. Szybki upadek caratu był efektem wyczerpującego udziału Rosji w pierwszej wojnie światowej i tym samym załamania się nastrojów społecznych, a także upadku autorytetu samego monarchy Mikołaja II, który zaczął polegać na doradztwie mnicha Rasputina, czyniąc z niego wszechwładną osobę w Imperium Rosyjskim²1 . Po upadku Rządu Tymczasowego, którym najpierw kierował Gieorgij Lwow, a następnie Aleksander Kiereński, władzę w państwie przejęli bolszewicy i ustanowili Rząd Komisarzy Ludowych. Pomimo zakończenia pierwszej wojny światowej w Rosji Radzieckiej trwała wyniszczająca wojna domowa pomiędzy Armią Czerwoną utworzoną przez bolszewików a wojskami białych dowodzonych przez carskich generałów nieakceptujących radzieckiego rządu² .

\section{Realizacja aspiracji mocarstwowych ZSRR}

Po zakończeniu wojny domowej i umocnieniu władzy przez bolszewików w 1922 r. powstał Związek Socjalistycznych Republik Radzieckich (ZSRR). Po śmierci lidera rewolucji październikowej Włodzimierza Lenina, w 1924 r., władzę w ZSRR prze-

\footnotetext{
18 G. Jukes, The Russo-Japanese War 1904-1905, Oxford 2002, s. 79.

19 Tamże, s. 85-86.

20 T. Chapman, Imperial Russia, s. 139.

21 L. Bazylow, P. Wieczorkiewicz, Historia Rosji, s. 376.

22 Zob. szerzej: E. Acton, Rosja. Dziedzictwo caratu i władzy radzieckiej, tłum. J. Stawiński, Warszawa 2013, s. 197.
} 
jął Józef Stalin. Nowy przywódca odsunął oponentów, m.in. Lwa Trockiego, Lwa Kamieniewa i Grigorija Zinowiewa, umocnił swoją pozycję w państwie i stał się niekwestionowanym liderem politycznym w kraju.

W pierwszych latach swojego istnienia Rosja Radziecka (potem ZSRR) spotykała się z nieufnością i ostracyzmem państw w Europie i na świecie. Bolszewicy nie uznawali ciągłości państwowej z Rosją carską i nie chcieli brać odpowiedzialności za zobowiązania z tamtego okresu. W związku z tym Rosja Radziecka była zagorzałym przeciwnikiem traktatu Ligi Narodów, uznając ją za umocnienie dominacji państw reprezentujących „stary” arystokratyczny porządek i nastawionych wrogo do rewolucji bolszewickiej. Dopiero nawiązywanie relacji handlowych z ZSRR ułatwiło niektórym państwom stosunki dyplomatyczne. Odbywało się to jednak bardzo powoli i do końca 1923 r. stosunki dyplomatyczne z ZSRR miało zaledwie 10 państw, w tym Polska, Niemcy, Turcja czy Afganistan ${ }^{23}$.

W 1922 r. pomimo nieufności i izolacji Rosji Radzieckiej na arenie międzynarodowej została ona zaproszona na konferencję dotyczącą spraw gospodarczych w Genui. Z punktu widzenia władz rosyjskich udział w tym wydarzeniu był rzeczą ważną, tym bardziej że w 1921 r. w obliczu katastrofy żywnościowej Lenin wprowadził Nową Politykę Ekonomiczną (NEP), pozwalając na prywatną przedsiębiorczość, a przy okazji na współpracę gospodarczą z państwami Zachodu. Lenin liczył na pożyczki i wsparcie finansowe. Chciał w ten sposób przywrócić w Rosji stabilność gospodarczą $^{24}$. Rosja Radziecka odniosła na konferencji podwójny sukces. Po pierwsze, przełamała izolację międzynarodową i rozpoczęła okres sukcesywnego nawiązywania stosunków dyplomatycznych (relacje z Wielką Brytanią zostały nawiązane w 1924 r., z USA dopiero w 1933 r.). Po drugie, radziecki komisarz ludowy spraw zagranicznych Gieorgij Cziczerin i szef dyplomacji niemieckiej Walther Rathenau zawarli w Rapallo pod Genuą układ o daleko idącej współpracy w wymiarze politycznym i militarnym. Układ ten wstrząsnął Europą, a szczególnie Polską i innymi państwami Europy Środkowo-Wschodniej. Stanowił także zapowiedź skonsolidowanej niemiecko-radzieckiej kooperacji aż do $1941 \mathrm{r}^{25}$

W ciągu kilku lat istnienia w polityce zagranicznej ZSRR udało się pogodzić dwa wykluczające się elementy - ideę permanentnej rewolucji i uznanie oraz jed-

23 W. Dobrzycki, Historia, s. 384-385.

24 C. Fink, THE NEP in Foreign Policy: The Genoa Conference and Treaty of Rapallo, [w:] Soviet Foreign Policy 1917-1991: A Retrospective, ed. by G. Gorodetsky, London-New York 2013, s. 12.

25 Tamże, s. 15. 
noczesną ochronę granic nowo powstałej Rosji Radzieckiej/ZSRR. Idea permanentnej rewolucji, propagowana przez Lwa Trockiego i jego zwolenników, nie została zrealizowana m.in. z powodu przegranej wojny z Polską w latach 1918-1920, ale także z przyczyn wewnętrznej walki o władzę. Trockiści przegrali, a sam Trocki został odsunięty od kierownictwa partii bolszewickiej i z czasem skazany na banicję. Z powodu problemów wewnętrznych, a także z obawy przed zewnętrzną interwencją, czego wówczas nie można było wykluczyć, ideę permanentnej rewolucji i braku kompromisu z Zachodem trzeba było odsunąć na rzecz umocnienia rewolucji w jednym państwie z bezpiecznymi granicami. Lenin nazywał takie działanie taktyką „wytchnienia” (pieredyszka), a układ z Rapallo był tego elementem ${ }^{26}$.

W następnych latach istnienia ZSRR w dalszym ciągu próbował legitymizować swoją obecność na arenie międzynarodowej, co ostatecznie zakończyło się sukcesem. Sprzyjała temu zmiana na stanowisku Wysokiego Komisarza ds. Zagranicznych. Cziczerina zastąpił w 1930 r. Maksym Litwinow, który proklamował tzw. „politykę pokojową". Polegała ona na uregulowaniu relacji z demokracjami Zachodu w obliczu kształtowania się państw faszystowskich ${ }^{27}$. Wiadomo już było wtedy, że idea rewolucyjnej konfrontacji z „państwami imperialistycznymi” nie zostanie zrealizowana i ZSRR w swojej polityce zagranicznej został zmuszony, aby realizować cele przez działania dyplomatyczne. W efekcie tego ZSRR został zaproszony do komisji Ligi Narodów, której zadaniem było przygotowanie konferencji rozbrojeniowej. Na tejże konferencji Litwinow zaproponował „definicję agresora”. Wcześniej, w 1928 r., ZSRR stał się sygnatariuszem Paktu Brianda-Kellogga, najbardziej powszechnego porozumienia w okresie międzywojennym, dotyczącego wyrzeczenia się wojny $\mathrm{w}$ stosunkach międzynarodowych ${ }^{28}$. Ponadto ZSRR zawarł szereg paktów o nieagresji z sąsiadami, w tym z Polską w 1932 r. Wszystkie te inicjatywy przyczyniły się do akceptacji w środowisku międzynarodowym i uznania ZSRR za państwo respektujące zasady wspólistnienia międzynarodowego. W rezultacie ZSRR został w 1934 r. zaproszony do Ligi Narodów ${ }^{29}$. Zwrócenie uwagi społeczności międzynarodowej na międzynarodową aktywność ZSRR i tym samym jej odwrócenie od spraw wewnętrznych pozwoliło Stalinowi na pełne umocnienie swojej władzy i realizację

26 G. Gorodetsky, The Formulation of Soviet Foreign Policy: Ideology and Realpolitik, [w:] Soviet Foreign Policy, s. 30-31.

27 L. Bazylow, P. Wieczorkiewicz, Historia Rosji, s. 433-434.

28 W. Dobrzycki, Historia, s. 385-386.

29 Szerzej zob. A.H.M. van Ginneken, Historical Dictionary of the League of Nations, Lanham-Toronto-Oxford 2006, s. 174-175. 
planu bezwzględnej kolektywizacji i industrializacji w Związku Radzieckim. Przemiany te dokonywały się kosztem życia milionów obywateli (m.in. głód na Ukrainie w latach 1932-1933).

Nie oznaczało to oczywiście, że ZSRR w polityce zagranicznej całkowicie zrezygnował z realizowania aspiracji mocarstwowych i ekspansji swoich wpływów. „Polityka kamuflażu” nie trwała długo. W obliczu zmian zachodzących w Europie i na świecie ZSRR zaczął zmieniać swoje nastawienie zarówno do Niemiec, już pod rządami Adolfa Hitlera, jak i do Wielkiej Brytanii czy Francji. Stalin, widząc defensywną politykę brytyjską i francuską przy jednoczesnej ekspansji na Dalekim Wschodzie Japonii połączonej Paktem Antykominternowskim z Niemcami, skłonił się ku zmianom w relacjach z państwami europejskimi. Rezultatem tego była zmiana na stanowisku Wysokiego Komisarza Ludowego ds. Zagranicznych, na którym Litwinowa zastąpił zorientowany na porozumienie z Niemcami Wiaczesław Mołotow. Odsunięcie Litwinowa oznaczało koniec współpracy z zachodnimi demokracjami i jednocześnie zakończenie jakichkolwiek działań ze strony ZSRR na rzecz wielostronnego i zbiorowego bezpieczeństwa ${ }^{30}$. Ponadto katalizatorem zmiany polityki zagranicznej ZSRR w 1939 r. w kierunku Niemiec była obawa wojny na dwa fronty, od zachodu z Niemcami i od wschodu z Japonią. Tym bardziej że w tym czasie doszło już do dwóch starć sił radzieckich z armią japońską, od kilku lat kontrolującą Mandżurię. Najpierw w 1938 r. nad jeziorem Chasan, a w kolejnym roku nad rzeką Chałchin-Gol ${ }^{31}$.

Kulminacją współpracy ZSRR z Trzecią Rzeszą był Pakt Ribbentrop-Mołotow zawarty 23 VIII 1939 r., w którym strony radziecka i niemiecka uzgodnily podział stref wpływów w Europie Środkowo-Wschodniej. Przyznanie w tym układzie ZSRR wschodnich ziem Polski, Besarabii, Łotwy, Estonii, a także Finlandii podkreślało radzieckie aspiracje mocarstwowe dość długo skrywane, kiedy resortem spraw zagranicznych kierował Litwinow. W rzeczywistości był to ten sam mechanizm realizowania polityki zagranicznej na rzecz ekspansji terytorialnej, jaki prowadziła Rosja w okresie panowania dynastii Romanowów.

Na początku drugiej wojny światowej ZSRR zaczął realizować w pełni postanowienia zawartego tuż przed jej wybuchem paktu. 17 września Armia Czerwona wkroczyła na wschodnie ziemie Polski, używając jako pretekstu ochrony mniejszości narodowych - białoruskiej i ukraińskiej. W odniesieniu zaś do polsko-radzieckiego

\footnotetext{
30 J. Haslam, Litvinov, Stalin and the Road Not Taken, [w: ] Soviet Foreign Policy, s. 58.

31 L. Bazylow, P. Wieczorkiewicz, Historia Rosji, s. 435.
} 
paktu o nieagresji z 1932 r. władze radzieckie stanowczo odrzucały jakiekolwiek zarzuty o złamanie tej umowy, argumentując, że 17 IX 1939 r. Polska nie istniała jako państwo. Radziecki atak na Finlandię 30 XI 1939 r. całkowicie odkrył zamiary ZSRR i realizację jego założeń ekspansji terytorialnej w ramach ustalonej dla ZSRR w Pakcie Ribbentrop-Mołotow strefy wpływów.

Niespodziewany atak Trzeciej Rzeszy na ZSRR 22 VI 1941 r. był dla Stalina zaskoczeniem. ZSRR został zmuszony do całkowitej zmiany swojej polityki zagranicznej. Odejście od indywidualnych działań opartych na układzie z Niemcami zostało zastąpione przez zbiorowe działanie w gronie aliantów, tzw. Wielkiej Czwórki, w ramach której zgodnie z ideą Roosevelta obok USA i Wielkiej Brytanii miejsce przypadło Chinom reprezentowanym wtedy przez Czang Kaj-Szeka, a także właśnie Związkowi Radzieckiemu.

W ówczesnej sytuacji ZSRR miał dwa rozwiązania w kontekście relacji z aliantami. Pierwsza opcja - „kooperatywna” - zakładała współpracę przy jednoczesnym zawężeniu pola w zakresie działań indywidualnych, druga zaś stanowiła pewną formę „kontynuacji” polityki zagranicznej ZSRR, a więc podejścia unilateralnego z zachowaniem szerokiej swobody działania. Za kooperatywnym podejściem optował szczególnie Litwinow, pełniący w latach 1941-1943 funkcję radzieckiego ambasadora w USA. Z kolei Mołotow zdecydowanie optował za unilateralizmem i próbował przekonać Stalina do swojej koncepcji ${ }^{32}$. Dramatyczne wydarzenia w pierwszych miesiącach inwazji niemieckiej na ZSRR zmusiły Stalina do szerokiej współpracy $\mathrm{z}$ aliantami. Efektem tego był m.in. zawarty w Londynie w lipcu $1941 \mathrm{r}$. układ Sikorski-Majski przywracający relacje dyplomatyczne pomiędzy ZSRR a rządem polskim. Trudno sobie wyobrazić, aby w warunkach kooperacji z Niemcami rząd radziecki zdecydował się na taki krok przed 22 VI 1941 r.

Uwarunkowania drugiej wojny światowej sprawiły, że ZSRR był zobligowany do uczestnictwa w spotkaniach „na szczycie”, których celem było ustalenie założeń ładu powojennego. We wrześniu 1941 r. ZSRR podpisał Kartę Atlantycką, a począwszy od konferencji w Teheranie w 1943 r., Związek Radziecki wraz z USA i Wielką Brytanią negocjował podział strefy wpływów. Do potwierdzenia lub zawarcia kolejnych ustaleń doszło następnie na konferencji w Jałcie w lutym 1945 r. i na konferencji w Poczdamie (lipiec-sierpień 1945).

32 A. Filitov, The Soviet Union and the Grand Alliance: The Internal Dimension of Foreign Policy, [w:] Soviet Foreign Policy, s. 99. 
Zakończenie drugiej wojny światowej, a w konsekwencji eliminacja zagrożenia ze strony hitlerowskich Niemiec oraz Japonii na Dalekim Wschodzie, skłoniło Stalina do odejścia od formuły kooperacji z USA i Wielką Brytanią. Różnice interesów m.in. w sprawie Niemiec i wszelkie inne okoliczności tuż po drugiej wojnie światowej sprawiły, że pojawiła się możliwość działań indywidualnych bez potrzeby wspólnego uzgadniania postanowień. ZSRR zatem po okresie wojny z Trzecią Rzeszą wrócił do tradycyjnego modelu swojej polityki zagranicznej. Warto przy tym zaznaczyć, że postawa USA w tym zakresie była bardzo zbliżona ${ }^{33}$. Obydwa mocarstwa uświadomily sobie szansę na realizację indywidualnych, ponad regionalnych interesów na rzecz umacniania swojej strefy wpływów.

Z punktu widzenia ZSRR ekspansja terytorialna miała charakter ideologiczny, co oznaczało rozszerzanie się strefy opanowanej przez komunizm, ale także wymiar związany z bezpieczeństwem. ZSRR nauczony doświadczeniami niemieckiego blitzkriegu z 1941 r., inwazji kontynentalnych z czasów carskich w okresie pierwszej wojny światowej i podczas kampanii napoleońskiej na początku XIX w., szczególnie dbał o zabezpieczenie swoich granic. Z tego powodu kluczowe znaczenie dla ZSRR miała Polska, którą zgodnie z założeniami Stalina należało podporządkować Związkowi Radzieckiemu ${ }^{34}$.

Ponadto po wojnie uaktywnily się liczne animozje między ZSRR a Zachodem, wcześniej skrywane przez lata wojny z racji celów wymagających współdziałania. Dojście Harry’ego Trumana do władzy w USA zmieniło relacje z ZSRR. Truman zaczął aktywnie ograniczać ekspansję komunizmu, m.in. w Grecji i Turcji, które mogły w owym czasie łatwo znaleźć się pod wpływami ZSRR. Konflikt był nieunikniony, a świat wszedł w okres zimnej wojny i wyścigu zbrojeń z bronią nuklearną na czele ${ }^{35}$.

Drażliwa sprawa przyszłości Niemiec poróżniła dawnych aliantów i w efekcie powstały dwa państwa niemieckie, a sam Berlin został podzielony. Kontrowersyjna okazała się także kwestia reparacji niemieckich. Związek Radziecki liczył na rozwiązanie tej sprawy na swoją korzyść, mając w zanadrzu argumenty dotyczące ogromnego zniszczenia infrastruktury podczas wojny z Trzecią Rzeszą. Pierwotnie podczas konferencji w Jałcie ustalono wysokość reparacji na 20 mld USD, z czego połowa miała przypaść Związkowi Radzieckiemu. W rzeczywistości niemieckie rezerwy zło-

\footnotetext{
33 M. Narinsky, Soviet Foreign Policy and the Origins of the Cold War, [w: ] Soviet Foreign Policy, s. 105.

34 R. McMahon, Cold War: A Very Short Introduction, Oxford-New York 2003, s. 11.

35 Zob. szerzej: E. Acton, Rosja, s. 278-280.
} 
ta i aktywa zostały zajęte przez USA i Wielką Brytanię, które w późniejszym czasie niechętnie przekazywały środki na rzecz reparacji w niemieckiej strefie kontrolowanej przez ZSRR ${ }^{36}$.

Zarysowująca się ostra rywalizacja na linii Wschód-Zachód szybko doprowadziła do powstania bloków polityczno-militarnych, które przez następne dziesięciolecia stanowiły emblemat zimnej wojny. W 1949 r. z inicjatywy USA podpisano Traktat Waszyngtoński, na bazie którego powstał Sojusz Północnoatlantycki (NATO). W odpowiedzi ZSRR zainicjował powołanie do życia Układu Warszawskiego w 1955 r., który miał stanowić przeciwwagę dla NATO w Europie.

Zimna wojna pojawiła się także w wielu miejscach poza Europą i z czasem ogarnęła cały świat. W 1949 r. Związek Radziecki wszedł w posiadanie broni nuklearnej i doprowadził do wyrównania potencjału nuklearnego. W tym samym roku powstała Chińska Republika Ludowa (ChRL), na której czele stanął Mao Zedong. Pomimo różnych trudności w relacjach chińsko-radzieckich po drugiej wojnie światowej, w 1949 r., m.in. ze względu na nabierającą rozpędu zimną wojnę, Stalin zaczął traktować chińskich komunistów po partnersku. W ZSRR dostrzeżono szansę ekspansji komunizmu w Chinach (pomimo różnic ideologicznych) i szansę na odsunięcie zagrożenia ze strony USA daleko od radzieckich granic ${ }^{37}$.

W 1950 r. wybuchła wojna w Korei, pierwsza poważna odsłona zimnej wojny. Sam konflikt był konsekwencją odejścia od porozumień międzysojuszniczych zawartych w Moskwie w 1945 r. Zaistniała wówczas nawet groźba użycia broni atomowej ze strony USA ${ }^{38}$.

W tym samym okresie postępował etap stalinizacji w państwach Europy Środkowo-Wschodniej, które znalazły się w strefie wpływów ZSRR. Koniec lat czterdziestych i początek lat pięćdziesiątych jest do dziś uznawany za najbardziej represyjną odsłonę rządów komunistycznych. Partie komunistyczne za wszelką cenę podjęły się umocnienia swojej władzy i eliminacji wrogów. W wielu krajach przeprowadzano znane już z lat trzydziestych w ZSRR procesy pokazowe, często samych komunistów, m.in.: w Czechosłowacji proces Rudolfa Slánskiego i jego współtowarzyszy, skazanego na śmierć i straconego w 1952 r., proces László Rajka na Węgrzech oskarżonego

\footnotetext{
36 J. Kukułka, Historia współczesna stosunków międzynarodowych 1945-1996, Warszawa 1997, s. 25, 32.

37 D. Henzig, The Soviet Union and Communist China 1945-1950: The Arduous Road to the Alliance, London-New York 2015, s. 150-155.

38 J. Kukułka, Historia współczesna, s. 94-99.
} 
o działalność kontrrewolucyjną, który zakończył się jego egzekucją w 1949 r., czy w Bułgarii proces skazanego w tym samym roku na śmierć Trajczo Kostowa.

W Polsce rozpoczęły się masowe aresztowania dowódców i członków Armii Krajowej, Narodowych Sił Zbrojnych czy Zrzeszenia Wolność i Niezawisłość. Wyroki śmierci po postawieniu fałszywych oskarżeń wykonano na znanych dowódcach sił partyzanckich z czasów okupacyjnych, m.in. generale Emilu Fieldorfie „Nilu”, rotmistrzu Witoldzie Pileckim czy ppłk. Łukaszu Cieplińskim. Wielu działaczy socjalistycznych sympatyzujących z komunizmem także znalazło się w więzieniu. Władysław Gomułka, późniejszy pierwszy sekretarz PZPR, został w 1951 r. aresztowany i oskarżony o współpracę z obcym wywiadem i nacjonalizm. Celem takich działań było umocnienie władzy komunistycznej, ale zgodnie z wytycznymi ZSRR i samego Stalina, który chciał mieć na czele wszystkich państw komunistycznych bezwzględnie oddanych sobie polityków. Z kolei w Czechosłowacji odsunięto w 1948 r. od władzy Edvarda Beneša, a partia komunistyczna przejęła pełnię władzy. Według wielu badaczy sposób przejęcia władzy przez komunistów w Czechosłowacji miał kluczowe znaczenie w zmianie polityki USA w stosunku do ZSRR ${ }^{39}$.

W ten sposób w Polsce umocnił swoją władzę Bolesław Bierut, w Czechosłowacji Klement Gottwald, na Węgrzech zaś „uczeń” Stalina - Mátyás Rákosi. W Bułgarii po śmierci Georgi Dymitrowa w 1949 r., na czele partii stanął Wyłko Czerwenkow, który na wzór stalinowski umacniał swoją władzę i przeprowadzał reformy w ramach ustanawiania systemu komunistycznego. Niemiecka Republika Demokratyczna również przeszła szybką fazę stalinizacji i władzę przejęła tam Socjalistyczna Partia Jedności Niemiec (Sozialistische Einheitspartei Deutschlands - SED), na czele której stanął Otto Grotewohl, który od 1949 r. pełnił urząd premiera NRD ${ }^{40}$.

Natomiast wyłamanie się z bloku radzieckiego nastąpiło w wypadku Jugosławii. Drogi Stalina i Josipa Broza-Tito dość szybko się rozeszły. Przez wzgląd na dużą samodzielność i aktywność Tity w przestrzeni bloku wschodniego pomiędzy ZSRR a Jugosławią postępowała daleko idąca nieufność, która zaowocowała rozłamem. Jugosławia nie przystąpiła do utworzonej w 1949 r. Rady Wzajemnej Pomocy Gospodarczej (RWPG) i skierowała się ku kontaktom z państwami Zachodu ${ }^{41}$.

Kontrola i ucisk państw Europy Środkowo-Wschodniej wpisywały się w imperialną politykę Związku Radzieckiego, który pomimo odmienności ustrojowej i po-

\footnotetext{
39 Tamże, s. 51.

40 Tamże, s. 49.

41 Tamże, s. 53.
} 
tępienia polityki Rosji carskiej wpisywał się w całość mechanizmów prowadzących do umocnienia statusu mocarstwa, tak samo jak to czyniło przed $1917 \mathrm{r}$. Imperium Rosyjskie. Można rzec, że zmienił się system polityczno-gospodarczy, lecz nie zmieniły mechanizmy prowadzenia imperialnej polityki zagranicznej.

W późniejszym okresie imperialna polityka radziecka utrzymywania swoich satelitów za wszelką cenę prowadziła do wielu tragicznych wydarzeń. Dobitnym tego przykładem jest rewolucja na Węgrzech w 1956 r. stłumiona przez interwencję radziecką, niepokoje w Czechosłowacji w 1968 r., które zakończyły się interwencją wojsk ZSRR, Polski i NRD, i w końcu zmasowane strajki i działania „Solidarności” w Polsce w latach 1980-1981, które zakończyły się wprowadzeniem stanu wojennego przez gen. Wojciecha Jaruzelskiego. Do dziś nie ma pewności, czy gdyby stan wojenny nie został w 1981 r. wprowadzony, to Polska, podobnie jak w przeszłości inne państwa bloku komunistycznego, nie stałaby się obiektem interwencji wojsk radzieckich.

Śmierć Stalina w 1953 r. zakończyła pierwszy etap zimnej wojny. Nowe kierownictwo w ZSRR po początkowych zawirowaniach zwiastowało zmiany w polityce zagranicznej państwa. Ku takiemu myśleniu skłaniały proces destalinizacji, a następnie przejęcie władzy przez Nikitę Chruszczowa. Istniały realne przesłanki, że w ówczesnym czasie pomiędzy USA i ZSRR mogłoby dojść do „pokojowego współistnienia”. Mimo że wzajemne relacje nadal były ostrożne i obydwie strony nie wyzbyły się działań ewidentnie wymierzonych w przeciwnika (np. autoryzacja programu U2 przez prezydenta Dwighta Eisenhowera), doszło do kilku spotkań, których celem było unormowanie relacji. Spektakularnym wydarzeniem była wizyta Chruszczowa w Camp David w Stanach Zjednoczonych we wrześniu 1959 r. ${ }^{42}$

Powrót do zimnej wojny w formie jak przed $1953 \mathrm{r}$. rozpoczął incydent z zestrzeleniem amerykańskiego samolotu szpiegowskiego U2 nad terytorium Związku Radzieckiego w maju 1960 r. W efekcie nie doszło do kontynuacji rozmów amerykańsko-radzieckich rozpoczętych w Camp David. W 1961 r. wybuchł kryzys berliński, który zakończył się budową muru oddzielającego Berlin Zachodni od NRD.

Za apogeum zimnej wojny jest uznawany kryzys kubański z 1962 r. Po tym jak rewolucjoniści pod dowództwem Fidela Castro obalili proamerykańskiego dyktatora Fulgencio Batistę w 1959 r., Kuba położona niedaleko wybrzeży USA stała się ogromnym zagrożeniem dla interesów politycznych USA na obszarze zachodniej hemisfery. Castro od początku swoich rządów zawarł sojusz z ZSRR. Władze radzieckie nie mo- 
gły nie skorzystać z szansy utworzenia swojej strefy wpływu tuż przy terytorium USA. John Kennedy - prezydent USA - liczył na to, że rewolucyjny rząd uda się jeszcze obalić z pomocą kubańskich imigrantów. Jednak nieudana operacja w Zatoce Świń w kwietniu 1961 r. całkowicie pogrzebała szanse na powrót Kuby do amerykańskiej strefy bezpośredniego oddziaływania. Rozmieszczenie radzieckich rakiet średniego zasięgu na Kubie stało się dla USA szokującym odkryciem. Trzeba jednak podkreślić, że z punktu widzenia ZSRR była to symetryczna odpowiedź na rozmieszczenie amerykańskich pocisków balistycznych w Turcji. Presja amerykańska i żądania kierowane wobec Chruszczowa z groźbą atomowego konfliktu w tle spowodowały, że radziecki przywódca jednak zdecydował się na wycofanie rakiet i demontaż wyrzutni rakietowych z Kuby. W ten sposób skończył się największy kryzys zimnej wojny ${ }^{43}$.

Po zażegnaniu kryzysu kubańskiego pozycja Chruszczowa w partii i wśród ścisłego kierownictwa ZSRR znacznie osłabła. Uważano, że Chruszczow jest zbyt nieprzewidywalny w swoich poczynaniach, by dalej mógł sprawować funkcję pierwszego sekretarza Komunistycznej Partii Związku Radzieckiego (KPZR). Ostatecznie został odsunięty od władzy i w 1964 r. przeszedł, co było precedensem w historii ZSRR, na polityczną emeryturę ${ }^{44}$.

Po objęciu stanowiska pierwszego sekretarza KPZR przez Leonida Breżniewa nastąpił okres przewartościowania w polityce zagranicznej ZSRR. Sprzyjały temu różne okoliczności. Po pierwsze, ChRL zaopatrzyła się w bombę wodorową i była na prostej drodze, aby wejść w posiadanie broni atomowej. Następnie ZSRR udało się wyrównać nuklearny potencjał militarny z USA, a Stany Zjednoczone wprowadzily, zainicjowaną przez Henry’ego Kissingera politykę „trójkątnej dyplomacji” w układzie USA-ZSRR-ChRL ${ }^{45}$. Przewartościowanie zmierzało w kierunku „odprężenia” między Wschodem i Zachodem, co w literaturze przedmiotu jest określane mianem „détente”, pomimo dramatycznych wydarzeń w bloku wschodnim, w tym inwazji ZSRR na Czechosłowację w 1968 r. zresztą przy udziale wojsk państw satelickich. Warto wskazać na to, że wszystko odbywało się w ramach realizacji „doktryny Breżniewa” traktującej o użyciu wszelkich środków w obronie socjalizmu. „Odprężenie” na tym etapie nie było zagrożone.

Jeszcze w 1963 r. (za czasów Chruszczowa) ZSRR wraz z USA i Wielką Brytanią zawarły „Układ o zakazie prób broni nuklearnej w atmosferze, w przestrzeni kosmicz-

\footnotetext{
43 R. McMahon, Cold War, s. 88-97.

44 E. Acton, Rosja, s. 295.

45 B. Lightbody, The Cold War, s. 66.
} 
nej i pod wodą" ${ }^{46}$. Jego podpisanie wyrażało intencje ZSRR i USA ostudzenia gorącej atmosfery po kryzysie kubańskim i było zwiastunem powoli zbliżających się zmian w relacjach amerykańsko-radzieckich. Wprawdzie działania odnoszące się do „détente" wyhamowały po zaangażowaniu Stanów Zjednoczonych w wojnę w Wietnamie w 1964 r., powoli jednak obydwa supermocarstwa skłonne były standaryzować swoje działania w wymiarze globalnym. Kolejnym ważnym elementem wpisującym się w „détente” było zawarcie w 1968 r. istotnego porozumienia w kontekście posiadania broni atomowej - Układu o nierozprzestrzenianiu broni jądrowej (Non-Proliferation Treaty) ${ }^{47}$. Traktat był otwarty i do czasów obecnych zaledwie kilka państw pozostaje poza nim (Indie, Pakistan, Izrael, Korea Północna i Sudan Południowy).

Wizja rozbrojenia i opanowania wymykającego się spod kontroli wyścigu zbrojeń skłoniła ZSRR i USA do rozmów na rzecz ograniczania stosowania niektórych rodzajów broni.

W 1969 r. zaczęly się rokowania rozbrojeniowe określane mianem SALT (Strategic Armaments Limitation Talks). Było to związane z rosnącymi obawami decydentów zarówno radzieckich, jak i amerykańskich w związku z pojawieniem się coraz bardziej zaawansowanych technologii militarnych. W latach sześćdziesiątych Związek Radziecki i USA weszly w posiadanie wielogłowicowych rakiet strategicznych ${ }^{48}$ oraz systemów antyrakietowych, które miały neutralizować pierwsze uderzenie ${ }^{49}$. Nowe rozwiązania technologiczne znacznie zwiększały koszty wyścigu zbrojeń i stwarzały coraz większe zagrożenie w wypadku ewentualnego konfliktu. Obydwa mocarstwa zdecydowały się na rokowania rozbrojeniowe, które toczyły się przez pięć miesięcy w 1970 r. w Wiedniu i w Helsinkach. Efektem tych rokowań był przede wszystkim traktat ograniczający rozmieszczanie systemów strategicznych (Anti-Ballistic Missile Treaty) zawarty w 1972 r. ${ }^{50}$ Ograniczenie odnosiło się do dwóch systemów w każdym z państw ${ }^{51}$.

\footnotetext{
46 Pełny tekst Układu zob.: Dz.U. 1963, nr 52, poz. 288.

47 Dz.U 1970, nr 8, poz. 60.

48 Określane w j. angielskim skrótem MIRV (Multiple Independent Re-Entry Vehicle), w j. rosyjskim zaś jako РГЧ ИН (Разделяющаяся головнал часть с блоками индивидуального наведения).

49 W j. angielskim określane skrótem ABM (Anti-Ballistic Missile), w j. rosyjskim jako Противоракета.

50 Pełny tekst w j. angielskim dostępny na stronie Departamentu Stanu USA: https://20092017.state.gov/t/avc/trty/101888.htm\#text [dostęp: 22 IX 2020].

51 C. Calvocoressi, Polityka międzynarodowa po 1945 roku, Warszawa 1998, s. 54-55.
} 
„Détente” w drugiej połowie lat siedemdziesiątych XX w. zaczęło chylić się ku upadkowi. W 1976 r. prezydentem USA został Jimmy Carter, a na stanowisku sekretarza stanu Henry'ego Kissingera zastąpił Cyrus Vance. Zmieniło się wtedy spojrzenie USA na ZSRR, a sam Carter zaczął silnie akcentować aspekt poszanowania praw człowieka. Breżniew zdecydowanie odrzucał wszelkie zarzuty formułowane w tym zakresie wobec ZSRR. Jednak, mimo fali pogarszających się wzajemnych relacji, ZSRR na szczycie w Wiedniu w 1979 r. zdecydował się podpisać kolejny układ rozbrojeniowy (SALT II $)^{52}$. Zawarcie tego układu mogło dawać nadzieję, że radziecka i amerykańska polityka z czasów „odprężenia” wrócą na właściwe tory. Interwencja radziecka w Afganistanie, rozpoczęta 24 XII 1979 r. całkowicie pogrzebała te szanse, a sam układ SALT II nie wszedł w życie.

Długotrwała formuła „odprężenia” wypaliła się. Można wskazać, że zarówno ZSRR, jak i USA odmiennie rozumiały to pojęcie. Ponadto do zmiany sytuacji przyczyniła się także zaostrzająca się rywalizacja dwóch mocarstw w Trzecim Świecie ${ }^{53}$.

Na początku lat osiemdziesiątych ZSRR przyjął bardzo ostrą politykę wobec USA. Pierwszy sekretarz KPZR Jurij Andropow (następca zmarłego w 1982 r. Breżniewa) zapowiadał walkę z USA o każdy skrawek ziemi. Stany Zjednoczone radykalnie zwiększyły wydatki na zbrojenia. W 1983 r. prezydent Ronald Reagan określił ZSRR mianem „imperium zła” (evil empire) i wszczął program Inicjatywy Obrony Strategicznej (Strategic Defense Initiative), który przyczynił się do znacznego rozwoju technologicznego rakiet antybalistycznych ${ }^{54}$. Powolna niewydolność systemowa ZSRR, kryzys gospodarczy oraz kosztowna obecność Armii Czerwonej w Afganistanie powodowały, że USA zaczęły zyskiwać dużą przewagę, natomiast mocarstwowe zakusy ZSRR uległy wyraźnemu ostudzeniu.

Objęcie funkcji Sekretarza Generalnego KPZR przez Michaiła Gorbaczowa w 1985 r. wywołało na świecie spore zaskoczenie. Politykom Zachodu trudno było uwierzyć, że w spetryfikowanej strukturze aparatu komunistycznego ZSRR władzę mógł przejąć, jak to ujął były szef brytyjskiego MSZ Denis Healey, ktoś o tak ludzkim i sympatycznym obliczu ${ }^{55}$.

Początki rządów Gorbaczowa zwiastowały liczne zmiany, zwłaszcza w kierunku reform systemowych w ZSRR, co miało przekładać się też na politykę zagraniczną.

\footnotetext{
52 B. Lightbody, The Cold War, s. 70.

53 R. McMahon, Cold War, s. 142.

54 B. Lightbody, The Cold War, s. 97.

55 E. Acton, Rosja, s. 334.
} 
Wprowadzenie pieriestrojki (przebudowy) i głasnosti (jawności) miało usprawnić machinę społeczno-polityczną ZSRR i nadać jej nowy wizerunek. Gorbaczow od zarania swojego kierownictwa w KPZR miał świadomość, że nieuchronnie zbliżała się potrzeba rozwiązania kwestii niemieckiej ${ }^{56}$. Niewątpliwie też z czasem ta świadomość pomogła mu w zaakceptowaniu ciągu zdarzeń zmierzających do zjednoczenia Niemiec. Zapowiedź wycofania wojsk radzieckich z Afganistanu (co zostało ostatecznie wykonane w lutym 1989 r.) i zmiany, jakie zaszły w Polsce po okrągłym stole, stały się zwiastunem zmian w samym ZSRR.

„Nowe polityczne myślenie” Gorbaczowa nie stanowiło żadnej gry ani żadnej taktyki w polityce reżimu radzieckiego. Gorbaczow nadzwyczajnie dostrzegał potrzebę nowego spojrzenia na świat zewnętrzny. Potwierdzały to nie tylko jego reformatorskie idee, które wprowadzał w życie, ale też zmiany personalne przez niego dokonywane. Na stanowisku ministra spraw zagranicznych wieloletniego ministra Andrieja Gromykę zastąpił Eduard Szewardnadze. Stanowiło to pewną zapowiedź nadchodzących zmian w polityce zagranicznej ZSRR, a także szerzej nowej percepcji środowiska międzynarodowego ${ }^{57}$. Można rzec, że rozpad ZSRR ze względu na czynniki niewydolności systemowej był nieunikniony. Politycy tacy jak Gorbaczow czy Szewardnadze mieli świadomość sytuacji polityczno-gospodarczej, w jakiej znalazł się ZSRR w latach 1985-1991. Należy tu wspomnieć, że Gorbaczow, który do dziś jest oskarżany o demontaż Związku Radzieckiego, chciał przede wszystkim zreformować i odmienić politykę ZSRR, a nie doprowadzić do jego rozpadu. W tym zakresie na przełomie lat osiemdziesiątych i dziewięćdziesiątych drogi Gorbaczowa i wielu bliskich mu polityków „młodego” pokolenia (w tym Szewardnadzego) się rozeszły. Podobnie jak Szewardnadze uważał ówczesny pierwszy sekretarz w Moskwie Borys Jelcyn, który wcześniej krytykował Gorbaczowa za zbyt powolne reformy ${ }^{58}$. W 1991 r. stało się już faktem, że Gorbaczow przestał mieć realną siłę polityczną. Pucz Janajewa z sierpnia 1991 r. wyniósł do władzy Jelcyna, który potępił puczystów i wsparł wprawdzie Gorbaczowa, lecz w efekcie zajął po nim polityczne miejsce.

Upadek i koniec ZSRR został ostatecznie przypieczętowany zawarciem 8 XII 1991 r. tzw. porozumienia białowieskiego przez Borysa Jelcyna, Leonida Krawczuka i Stanisława Szuszkiewicza.

56 Zob. szerzej: A. Cherniaev, Gorbachev and the Reunification of Germany: Personal Recollections, [w:] Soviet Foreign Policy, s. 158-169.

57 I. Lebedev, International Affairs at the End of the Cold War, [w: ] Soviet Foreign Policy, s. 187-191.

58 G.W. Breslauer, Gorbachev and Yeltsin as Leaders, Cambridge 2002, s. 116-117. 


\section{Zakończenie}

Przedstawiona powyżej międzynarodowa aktywność polityczna, militarna oraz traktatowa Rosji carskiej, a w wypadku ZSSR dodatkowo aktywność ideologiczna, układają się w logiczny ciąg wykorzystywanych idei, sposobów myślenia i realnych zachowań. Wszystko: sposób myślenia, podejmowane działania (militarne, polityczne i gospodarcze) zarówno w Rosji carów, jak i w ZSSR zasadniczo miały jeden podstawowy, nadrzędny cel - budowę i utrzymanie coraz potężniejszego państwa rosyjskiego, a potem radzieckiego. Dążenie do rozwoju i potęgi jest immanentnie wpisane w każdy twór państwowy. Można by rzec, że jest to cecha naturalna państw. To, co wyraźnie wyróżnia myślenie rosyjskie o rozwoju i potędze państwa to stale towarzyszące przywódcom i podzielane przez rosyjskie, a potem radzieckie elity polityczne oraz intelektualne złożenie, że rozwój i budowanie potęgi są możliwe przede wszystkim przez ekspansję zewnętrzną.

Oczywiste jest, że historia zna wiele przypadków powstawania, rozwoju i upadku imperiów. Wiele z tych imperiów - istotna większość - budowało i buduje swoją potęgę przez ekspansję terytorialną na zewnątrz. Trzeba jednak wyraźnie podkreślić, że w wypadku carskiej Rosji i ZSSR była to cecha stała i istotnie determinująca politykę zagraniczną. Praktycznie większość podejmowanych wysiłków wewnętrznych koncentrowała się na budowaniu i wzmacnianiu siły na płaszczyźnie międzynarodowej albo była reakcją na sytuację międzynarodową.

Historia Rosji carskiej i ZSSR zna okresy mniejszej koncentracji na ekspansji zewnętrznej i międzynarodowej konfrontacji lub wręcz okresy wycofania się z płaszczyzny międzynarodowej i skupienia na sprawach i zmianach wewnętrznych. Bliższa analiza tych okresów wskazuje jednak dosyć jednoznacznie, że nie były to swobodne wybory przywódców i elit. Najczęściej pojawiała się wówczas pilna potrzeba aktywności w sprawach wewnętrznych spowodowana nadzwyczajnym nagromadzeniem ryzyka i trudności wewnętrznych zagrażających podstawom władzy carów lub przywódców komunistycznych.

Czasami defensywa na arenie międzynarodowej wynikała też ze szczególnie niekorzystnej sytuacji międzynarodowej, z przegranych wojen, a w konsekwencji szczególnej słabości mechanizmu państwowego.

Na przestrzeni niespełna 400 lat zmieniało się praktycznie wszystko: modele sprawowania władzy, modele życia społecznego, podstawowe idee organizujące społeczeństwa, modele gospodarcze, organizacja armii, uzbrojenie. Rosja carska 
z XVII w. i ZSSR u jego schyłku to z pewnością dwa bardzo różniące się byty państwowe. Jest jednak coś, co jest wspólne dla nich przez caly okres ich trwania. Niewątpliwie zarówno Rosja carska, jak i ZSSR uznawały imperializm za istotną determinantę trwania i rozwoju.

\author{
Nadesłany: 18 III 2020 \\ Nadesłany po poprawkach recenzyjnych: 23 XI 2020 \\ Zaakceptowany: 4 I 2021 \\ Dr hab. Sylwester Gardocki \\ Wydział Nauk Politycznych i Studiów Międzynarodowych \\ Uniwersytet Warszawski \\ ul. Śmiała 26 \\ 01-523 Warszawa \\ s.gardocki@uw.edu.pl
}

\title{
Resume
}

The aim of this article is to take a synthetic look at Tsarist Russia (from the $17^{\text {th }}$ century onwards) and the USSR through ideas and deeds which marked Russian political thinking and action and involved an intent to extend the influence to other countries or territories. In the first part, the main assumptions are presented together with real actions to implement the objectives of the foreign policy in Tsarist Russia. The second part is devoted to the imperial ambitions of the Soviet Union. The author aims at analysing the political assumptions and actual actions taken as part of the foreign policy of Tsarist Russia and the USSR. 